\title{
HISTORY OF RESEARCH AT THE ST. ANDREWS BIOLOGICAL STATION - A PERSPECTIVE
}

\author{
JENNIFER M. HUBBARD* \\ History of Science and Technology, Department of History, \\ Ryerson University, 350 Victoria Street, Toronto, ON M5B $2 \mathrm{~K} 3$
}

In 2008, it was my privilege to be a keynote speaker at the conference celebrating the one hundredth anniversary of the permanent biological station at St. Andrews, New Brunswick. The historical papers given by participating scientists and technical experts revealed the impressive breadth, diversity, importance and sheer relevance of studies undertaken at the St. Andrews Biological Station (herein called SABS) over its hundred years. The scope of investigations revealed how much has been missed by other experts who have analysed fisheries and aquatic science - notably historians of science, sociologists, and maritime legal scholars. Their focus has been on science relevant to the theory of fishing and the management of commercial populations. For example, at the 2016 Coastal Zone Canada Conference in Toronto, one speaker commented on the narrowness of fisheries biology as a field, and linked current sustainability problems to that supposedly narrow focus. However, the book inspired by the SABS centenary celebration - A Century of Maritime Science, Hubbard, Wildish and Stephenson (2016) - shows that a history focused only on the development and elaboration of the theory of fishing misses huge swathes of fisheries and coastal science. In fact, despite the breadth of science covered in the book, it does not showcase all of the important research streams at SABS! Fisheries and aquatic scientists have been doing a great deal more than most people realize.

Recent Canadian and international scholarship has highlighted that if we are to attain environmental sustainability, and in this context for the oceans, it is important that we encourage collaboration across disciplines - collaboration that draws together academics, scientists, sociologists, indigenous peoples, and experts of all kinds, including local fishers, fishing associations, and especially historians. 
A Century of Maritime Science shows that the rich and broad output of SABS was likewise only possible because scientists and technologists with many different kinds of expertise collaborated with each other in identifying problems and figuring out how to deal with them.

Many scientists tend to have quite narrow fields of specialization. The effectiveness of an organization like SABS, devoted to researching aquatic and marine species and their environment, relies in large part on having many different kinds of scientific specializations present in one establishment. At SABS, this has included vital contributions from ecotoxicology and pollution research, oyster and scallop and herring research, research programs on paralytic shellfish poisoning and other marine pathogens, physical oceanography, experimental flow studies and fish culture research. A Century of Maritime Science shows how a diverse group of SABS scientists and technologists have worked closely together to identify and understand problems, and mitigate or eliminate obstacles and problems wherever possible. Because of the close proximity of so many different experts, and the absence of isolated research silos, SABS has - even during times of diminished Federal support - remained able to respond flexibly to the increasing and shifting challenges faced by the marine environment, communities, fishers and fisheries. Its ongoing research has also offered insights into global issues such as climate change and the effects of persistent toxic chemicals. A Century of Maritime Science shows how, in order to sustain relevance and respond fluidly to local environmental challenges, researchers from many different backgrounds must be available to conduct a variety of research projects.

A Century of Maritime Science includes an introduction and two chapters written by historians of science, and ten chapters contributed by scientists who either worked at or had strong connections with the Biological Station. It was a real labour of love and patience on all our parts. The papers had to be substantially revised once we decided to publish through the University of Toronto Press. Getting the book through peer review, revisions, and copy and proof editing took many years longer than projected. I believe that the final result warrants the wait.

The first four chapters provide the historical context of the Atlantic Biological Station, now called SABS. The first chapter is by Eric Mills, one of the world's premier historians of oceanography. His chapter gives a brief history of Canadian science and the scientific organizations in the $19^{\text {th }}$ century which preceded and in a sense 
enabled the creation of the Board of Management of the Biological Stations of Canada. Of particular interest is the role and limitations of the Hydrographic Survey of Canada, and the Canadian Tidal and Current Survey. These surveys later assisted and were assisted by scientists at SABS. Elsewhere, in his recent book, The Fluid Envelope of Our Planet (Mills, 2009), Mills tells the story of the Scandinavian origin and spread of dynamic oceanography. The Canadian Fisheries Expedition was manned by scientific volunteers from SABS who worked in collaboration with Norwegian oceanographer and fisheries biologist, Johan Hjort. This event provided the first chance for Hjort's Scandinavian assistant, the oceanographer Johan Sandstrom, to spread the new techniques employed in dynamic oceanography beyond Norway and Sweden. ACentury of Maritime Science includes references to Mills's book and other sources that highlight the important international role of SABS.

Mary Needler Arai also provides a broad context, describing the role of and treatment of women who were marine biologists in marine biological institutions in British Columbia, Washington State, Atlantic Canada, and in university biology departments and American museums. Her analysis also includes several women scientists supported by the U.S. Fish Commission. Her chapter is of particular importance as it reflects the views and understanding of a third generation woman Ph.D. scientist, whose grandmother, Edith Berkeley, worked at the Pacific Biological Station, and whose mother, Alfreda Needler, worked at St. Andrews and Ellerslie sub-station in PEI. Alfreda Needler's research on the biology of oysters led to her making seminal contributions to the study of paralytic shellfish poisoning and identifying the causal microorganism.

My chapter on the emergence of Maximum Sustainable Yield (MSY), as a management goal for commercial fisheries, continues to situate the Biological Station and the contributions of its leading scientists within an international context. The Station gained federal funding because it fell within the British amateur-gentleman tradition of science for the public good, which had been copied by university and other gentlemen scientists in the Dominion of Canada. The goal of MSY emerged first in German scientific forestry, which also shared a view that enlightened science could help governments and societies develop natural renewable resources in a sustainable manner. The marriage between late Victorian and Progressive conservation ideals resulted in the goal of rational and efficient exploitation for 
maximum sustained yield for peak production. Leading German forester, Bernhard Fernow, introduced German scientific forestry to the United States; he later joined the University of Toronto where he introduced Atlantic Biological Station director,Archibald Gowanlock Huntsman, to these ideas. Huntsman was to introduce measures drawn from forestry science into post-war theories of fishing.

The final introductory chapter is by former station director, Robert L. Stephenson, who was responsible for convening the SABS centenary conference. He surveys the effects of shifting government science-management policies on the scientific programs and output of SABS from its origins up to its hundredth year. His admirably concise history describes the shift from volunteer to professional scientists hired through the Biological Board of Canada, and the Board's growth as the Fisheries Research Board of Canada after 1937. He also highlights the key role played by SABS as a kind of "nursery ground" for fisheries and aquatic scientists, since most Canadian marine scientists for many decades received their fundamental training through SABS. He underscores the effects of the uncertainty over the future of SABS from the time the station burned down in 1932 and was rebuilt by Huntsman without authorization, right up until substantial Federal reinvestment in the station took place in 2008. He also highlights the challenges faced when government line management replaced the earlier management model. Before this change, station directors administered and directed the different lines of research, overseen by a board formed of industry members, university academics within the Fisheries Research Board of Canada, and Department of Fisheries personnel. Funding for research also shifted to agencies such as NSERC, requiring scientists to spend less of their time actually doing research and more time applying for funding. The research output and service to public science by SABS scientists shown in this volume thereby appears all the more amazing, given these challenges.

The next eight chapters focus on individual research programs by scientists, technologists and scientific groups at SABS. Tim Foulkes leads the way, with a chapter on the contributions of technologists who supported the various research programmes at SABS with their expertise and ability to design and build specialized scientific equipment. I particularly like this chapter, as it fits in with a recent focus in the history of science: the role of the non-scientific experts without whom the scientists would have never accomplished their 
most important work. Foulkes's chapter also gives a hint of what daily life was like at the station, with the mention of data analyst and gourmet curry cook, A. Sreedharran. While he covers the technology challenges that SABS faced from its beginning, the main focus is on his work beginning in the early 1960s, assisting researchers who required specific tools, such as underwater towed vehicles equipped with cameras, for their stock assessments and other research. He describes the development of the various specialized underwater towed vehicles.

Fred Page and Blythe Chang survey the history of oceanography at St. Andrews, describing its hesitant and limited beginnings in the 1910s when lack of equipment restricted oceanographic work, and its flourishing after the station's hire of the first Canadian professional oceanographer, the self-trained Harry B. Hachey. Hachey was attracted from the University of New Brunswick (Fredericton) physics department to work at SABS, not only by the immediacy and urgency of research problems (such as the potential physical, climatic and fisheries effects of proposed hydroelectric dams around Passamaquoddy Bay), but also by the presence of numerous women scientists at the station. The work of Hachey and other oceanographers enabled SABS to survey the marine environment in Passamaquoddy Bay and the greater Bay of Fundy, as well as the Scotian Shelf, the Gulf of St. Lawrence, and as far afield as the waters around Newfoundland, Hudson Strait and Hudson Bay. The expertise built up before the Second World War allowed Hachey and newer oceanographers to offer important scientific assistance to the war effort, and ultimately led to the creation of the Bedford Institute of Oceanography in Dartmouth, Nova Scotia. They also fulfilled their mandate to assist fisheries investigations through providing the environmental information required by fisheries researchers. The always-changing ocean environment, in response to global temperature changes, for example, means that oceanographic research in support of fisheries, environmental sustainability and other issues is as vital as ever.

David Wildish and Shawn Robinson have contributed a chapter on the development of experimental flow studies at SABS, beginning in the 1960s. They write about the assistance required from technologists to build their flow research flumes and respirometers, and highlight the ways in which their research in turn assisted the research programmes of other SABS scientists. Their experimental 
flow studies investigated the effectiveness of filter feeding bivalves in different current strengths, and the rates at which chemical pollutants and naturally produced toxins were cleared from the bodies of filter feeders, studies which aided investigations of paralytic shellfish poisoning. Their studies of how swimming fish responded to different current strengths were used to assist SABS researchers investigating the effects of pesticides (e.g., fenitrothion) on salmon and trout in Maritime streams. Their investigation of how currents can scatter juvenile scallops, and how older scallops prevent displacement by strong currents, assisted SABS scallop researchers such as John Caddy. Wildish and Robinson's chapter shows, moreover, how seemingly abstract, basic science has real-world applications when used in clearly applied research programs.

The history of scallop research at SABS by John Caddy shows the fundamental importance of scallop research to the development of effective and successful national and international policies to ensure the sustainability of scallop fisheries. He also writes about how licensed private companies have adopted responsibility for monitoring commercial scallop grounds. Caddy's chapter is unique as he also comments on current issues in fisheries management, advocating for the use of spatial models and spatial considerations in understanding the structure and role of scallop populations in different locations, with reference to bottom substrates and prevailing ocean currents.

A highly personal account of the history of wild salmon research at St. Andrews is offered by Richard Peterson. The research focused on monitoring and attempting to increase the salmon populations, as well as on the effects of industrial pollutants and pesticides on Maritime salmon. He offers insights on the programme's character and characters through his personal perspective and anecdotes. The end of this important stream of SABS research sadly came with the discovery of the primary Atlantic salmon feeding grounds off Greenland in the early 1970s. The subsequent international fishing frenzy virtually annihilated this species. While the progressively fewer returning salmon have continued to be monitored, a recovery has been ruled out by the obstinate refusal of Greenland to shut down the diminishing sea fishery for salmon.

Jennifer Martin's chapter deals with the history of paralytic shellfish poisoning (PSP) and other shellfish toxicity research at SABS. The station became a world leader in algal toxin research, in part because the link between PSP, caused by a dinoflagellate that was 
renamed Alexandrium fundyense in 1985, was first recognized at SABS by Alfreda Needler. As well, the phenomenon of "red tide" was first recognized in the Bay of Fundy and was first investigated by SABS scientists. Jennifer Martin mentions that many other SABS researchers have contributed to research on paralytic shellfish poisoning and other shellfish toxins. She shows the very important role played by dedicated PSP researchers, including Carl Medcof, a world leader in the field, and other women researchers, notably Alfreda Needler, Viola Davidson and Carrie Lewis. Important breakthroughs were made by such PSP researchers in SABS' first century.

The theme of human-caused contamination and pollution by toxic chemicals is taken up by Peter Wells in the chapter on the history of ecotoxicology and environmental science at SABS. Its aquatic chemistry and toxicology program, sadly, was terminated a few years after the centenary conference of 2008 , despite its critical role in protecting aquatic resources. The chapter recounts how John Sprague, Don McLeese, Vlado Zitko, and other researchers at SABS, helped to develop and apply this newly emerging science from the late 1950s to the 1990s, in conjunction with other aquatic research programs around the world. This research was essential to determining factors that influence toxicity, identifying natural and human-generated toxic substances, the effects of pesticides, and determining the levels at which industrial effluent pollution harms the environment and specific organisms in lakes, streams, and the coastal and open ocean. This research is also vital to preserving or remediating local environments from the effects of dredging, industrial pollutants, pulp mills, fish farming and other activities, and supports researchers investigating issues in aquaculture and bivalve research, among others. Ecotoxicologists have collaborated with other SABS research programs, showing that ecotoxicology remains fundamental to understanding environmental stresses on commercial fisheries and farmed fish.

The final chapter is by former SABS director, Robert Cook. Cook describes the long history of research on aquaculture and fish hatcheries at SABS, beginning with the technical challenges of oyster and other bivalve culture, and investigations into the practices and shortcomings of provincial fish and lobster hatcheries. Many technical and political difficulties were encountered in the ultimately successful development of salmon farms. Of particular interest are Cook's descriptions of the network of federal, provincial and 
private agencies and organisations that came together to assist in the creation and success of the Atlantic salmon aquaculture industry. SABS researchers have been central to identifying and solving specific technical problems that have arisen and continue to occur in this industry, such as the problem of disease control using chemicals. Cook was a central figure in this story; his history provides valuable insights into how the Atlantic Canadian finfish aquaculture program emerged and grew in the latter part of the $20^{\text {th }}$ century.

A Century of Maritime Science does not cover the history of all of the important research programmes and people at SABS. However, it does give local citizens at St. Andrews, federal and provincial policy makers, and scientists and other scholars here and elsewhere, an idea of the depth, breadth and importance of the work that has been done at $\mathrm{SABS}$ in the $20^{\text {th }}$ century. This volume is unique in the history of marine science in its presentation of the history of diverse research programs, and its ability to allow readers to see how each strand, while appearing unique and sometimes esoteric, is profoundly connected with other research programs. It is also highly relevant to the general history of marine science, since many of the breakthroughs at St. Andrews are pertinent to global issues and have contributed to international developments in fisheries and coastal science. As a historian of science, I have been privileged to be involved in this book project and remain deeply impressed by the clear indications that the ideals of public service and dedication to solving economic and environmental problems are alive and well at SABS.

\section{REFERENCES}

Hubbard, J., Wildish, D.J., \& Stephenson, R.L. (2016). A Century of Maritime Science. The St. Andrews Biological Station. University of Toronto Press, Toronto, Buffalo, London. 477 p.

Mills, E.L. (2009). The Fluid Envelope of Our Planet. How the Study of Ocean Currents Became a Science. University of Toronto Press, Toronto, Buffalo, London. 434 p.

Note: The author was both a contributor to and an Editor of the book discussed in this article. This issue of PNSIS also has an independent review of the book. 